\title{
Density of mast cells and microvessels in minor salivary gland tumors
}

\author{
Manuela Torres Andion Vidal - Iguaracyra Barreto de Oliveira Araújo • \\ Clarissa Araújo Silva Gurgel • Francisco De Assis Caldas Pereira • \\ Deise Souza Vilas-Bôas • Eduardo Antônio Gonçalves Ramos • \\ Ivan Marcelo Gonçalves Agra • Adna Conceição Barros • \\ Valéria Souza Freitas • Jean Nunes dos Santos
}

Received: 5 August 2012 / Accepted: 2 October 2012 / Published online: 20 October 2012

(C) International Society of Oncology and BioMarkers (ISOBM) 2012

\begin{abstract}
The aim of this study was to investigate the density of mast cells and microvessels in minor salivary gland tumors. Forty-one cases of minor salivary gland tumors (pleomorphic adenoma, $n=10$; adenoid cystic carcinoma, $n=11$; mucoepidermoid carcinoma, $n=10$; and polymorphous low-grade adenocarcinoma) were investigated using immunohistochemistry for mast cell tryptase and von-Willebrand factor. Density of mast cells was higher in
\end{abstract}

M. T. A. Vidal $\cdot$ C. A. S. Gurgel $\cdot$ F. D. A. C. Pereira

A. C. Barros $\cdot$ J. N. dos Santos $(\square)$

Department of Oral Pathology, Laboratory of Surgical Pathology,

School of Dentistry, Federal University of Bahia,

Salvador, Bahia, Brazil

e-mail: jeanunes@ufba.br

I. B. de Oliveira Araújo

Department of Pathology,

Aristides Maltez Hospital and Federal University of Bahia,

Salvador, Bahia 40110-150, Brazil

D. S. Vilas-Bôas

Department of Bio-morphology, Institute of Health Sciences, Federal University of Bahia UFBA,

Salvador, Bahia, Brazil

E. A. G. Ramos

Gonçalo Moniz Research Center, Oswaldo Cruz Foundation,

Salvador, Bahia, Brazil

I. M. G. Agra

Department of Head and Neck Surgery, Aristides Maltez Hospital, Salvador, Bahia, Brazil

\section{S. Freitas}

Department of Health (Oral Pathology),

State University of Feira de Santana,

Feira de Santana, Bahia, Brazil mucoepidermoid carcinoma; however, no differences in the number of these cells were observed between the different types of tumors $(p>0.05)$. The number of mast cells was higher in periparenchymal areas in all tumors, but the difference was not significant $(p>0.05)$. Mucoepidermoid carcinoma showed the largest number of periparenchymal mast cells, whereas pleomorphic adenomas showed the smallest number of intraparenchymal mast cells $(p>0.05)$. The highest microvessel density was observed in mucoepidermoid carcinomas, being this difference statistically significant when mucoepidermoid carcinoma was compared to pleomorphic adenoma $(p=0.0034)$ and polymorphous low-grade adenocarcinoma $(p=0.004)$. Microvessel density was significantly higher in adenoid cystic carcinoma when compared to pleomorphic adenoma $(p=0.0406)$ and polymorphous low-grade adenocarcinoma $(p=0.0123)$. Comparison of mast cells and microvessel densities showed no significant difference between tumors. A quantitative difference in mast cells and microvessels was observed, particularly in mucoepidermoid carcinoma, a finding supporting the aggressive behavior of malignant salivary gland tumors without myoepithelial differentiation. Further studies are needed to determine the role of mast cells in angiogenesis, as well as in the development and biological behavior of these tumors.

Keywords Salivary gland tumors $\cdot$ Mast cell $\cdot$ Microvessels · Immunohistochemistry

\section{Introduction}

Tumors arising from the minor salivary glands account for $10-15 \%$ of all salivary gland tumors and are found in the 
palate, lips, buccal mucosa, tongue, and floor of the mouth, among other sites [1-3]. Minor salivary gland tumors are a highly heterogenous group because of their cytoarchitectural diversity and distinct biological behavior $[4,5]$. Therefore, various studies have tried to predict the course of these tumors [6-8]. According to Nguyen et al. [9], salivary gland tumors differ in terms of myoepithelial cell content, a fact that may influence the outcome of these tumors and their capacity to develop metastases.

Tumor growth and development are dynamic processes that are regulated by molecular changes triggered by the tumor cells themselves and microenvironmental conditions that favor cell survival and multiplication. These conditions include the adequate supply of oxygen and nutrients, as well as the supply of certain cytokines, growth factors, and cell components such as mast cells [10-12]. Mast cells are bone marrow-derived cells widely found in human tissues [13-15] which play an important role in allergic reactions, inflammation, and $\mathrm{T}$ cell-mediated immune responses [16]. In addition, these cells play a key role in the dynamic of tumor growth and development, influencing angiogenesis, tissue remodeling, and the host immune response [10, 16-18]. Mast cells are found primarily near the tumor where they interact with the tumor microenvironment through surface molecules, cytokines, and growth factors, contributing effectively to progression of the tumor [18-20].

Angiogenesis is a fundamental coordinated process that is required for tumor development and progression. Within this context, mast cells secrete growth factors and cytokines that participate in tumor angiogenesis $[9,20]$. Furthermore, these cells produce enzymes that degrade the extracellular matrix $[16,21]$ and cytokines that participate in immune response modulation [22]. Taken together, these factors facilitate tumor growth, invasion, and metastasis [23-25].

The tissue stroma plays an essential role in the preservation of epithelial tissues since minor alterations in these tissues are followed by corresponding changes in the stroma [26]. Therefore, this study investigated the distribution of mast cells (MCs) and microvessel density in a series of minor salivary gland tumors.

\section{Material and methods}

Following approval by the Ethics Commitee of School of Dentistry, Federal University of Bahia, Salvador, Bahia, Brazil, 41 minor salivary gland tumors were studied. The sample consisted of 10 cases of pleomorphic adenoma (PA), 11 cases of adenoid cystic carcinoma (ACC) (5 tubular, 5 cribriform, and 1 solid), 10 cases of low-grade mucoepidermoid carcinoma (MEC), and 10 cases of polymorphous low-grade adenocarcinoma (PLGA). They were retrieved from the Archives of the Pathological Anatomy Service,
Faculty of Dentistry, Federal University of Bahia, and from the Aristides Maltez Hospital, Salvador, Bahia. The histopathological diagnosis was revised and classified by an experienced oral pathologist (JNS) based on the current world health organization classification [27].

Cut sections $(3 \mu \mathrm{m})$ obtained from paraffin-embedded specimens were deparaffinized in xylene (two times for $10 \mathrm{~min}$ ) and absolute alcohol (two times for $5 \mathrm{~min}$ ) at room temperature. Antigen retrieval was performed by incubating the sections in $1 \%$ trypsin at $37^{\circ} \mathrm{C}$ for $30 \mathrm{~min}$ (three cycles of 10 min each) for mast cell tryptase antibody (1:50, clone AA1, Dako Corporation, Carpinteria, CA, USA) and in citrate, $\mathrm{pH} 6.0$, at $98{ }^{\circ} \mathrm{C}$ for $40 \mathrm{~min}$ for von-Willebrand factor (1:50, clone F8/86, Dako Corporation). Next, the sections were incubated with the primary antibody diluted in antibody diluent in addition to background-reducing components (Dako Corporation) at $4{ }^{\circ} \mathrm{C}$, overnight. The polymer (EnVision ${ }^{\mathrm{TM}}$, Dako Corporation) was then applied for $30 \mathrm{~min}$ at room temperature, followed by the development of the reaction with 3,3-diaminobenzidine (Dako Corporation) as chromogen solution for $5 \mathrm{~min}$ in a dark chamber. Afterward, sections were counterstained with Harris hematoxylin. Pyogenic granuloma specimens were used as positive control. The negative control consisted of replacement of the primary antibody with normal serum of the same isotype as the primary antibody.

The presence or absence of MCs in the different minor salivary gland tumors was determined using mast cell tryptase antibody. Positive cases were identified by brown staining of the cells. In addition, the shape of the cells was evaluated. The presence or absence of blood vessels in the different minor salivary gland tumors was evaluated using von-Willebrand factor. Positive cases were identified by brown staining of endothelial cells in areas of greatest confluence (hot spots).

Histological analyses consisted of the observation of MCs in the tumor stroma and parenchyma, avoiding areas of significant inflammation. Mast cells were classified as intraparenchymal or periparenchymal as described by our team [28].

Histomorphometric assessment was carried out by two trained observers under a high-definition light microscope at $\times$ 400 magnification (Axiostar Plus, Zeiss, Germany). Up to 10 high-power fields were analyzed, and the results were recorded with a digital camera (Axiocam Icc3, Zeiss). Mast cell count and vessel density per square millimeter ${ }^{2}$ were determined using specific software (Axiovision Rel 4.8, Zeiss, 2008), and mean counts were determined for each case. Microvessels were counted in a given area (in square millimeter), excluding those with a lumen $>50 \mu \mathrm{m}$ [29]. Both observers were unaware of the microscopic diagnosis and previous results.

The number of MCs in the tumors studied was used as a cut-off value to compare the distribution of these cells with microvessel density. For this purpose, each tumor type was 
divided into two groups (mast cell count $>$ median and mast cell count $<$ median), and these groups were compared.

Differences between groups were evaluated using the Kruskal-Wallis test, followed by Dunn's test and the MannWhitney test. All statistical calculations were performed using the GraphPad Prism 5.0 program (San Diego, USA). A $p$ value $<0.05$ was considered to be statistically significant.

\section{Results}

MCs were detected in all tumors studied. These cells were located often close to blood vessels and showed variable morphology (oval, elongated, or round). This cell population was concentrated in periparenchymal areas and was heterogeneously distributed, irrespective of the morphological pattern of the tumors, except for PA in which these cells were more concentrated in the fibrous capsule (Fig. 1). Degranulation of mast cells was observed in some cases. Few mast cells were detected in the parenchyma of normal salivary glands.

Although the density of MCs was higher in MEC, no significant differences in the number of MCs were observed between the different types of tumors studied ( $p=0.1310$; Kruskal-Wallis test). The number of MCs was higher in periparenchymal areas in all tumors studied, but the difference was not significant ( $p=0.1310$; Kruskal-Wallis test).

Comparison of the number of MCs between the histological subtypes of tubular (density: 7.6) and cribriform (density: 5.4) ACC showed no significant difference ( $p=0.5476$; MannWhitney test).

The analysis of periparenchymal MCs distribution revealed that MEC presented the largest number of mast cells (mast cell peri $_{1}=10.49$; mast cell intra $=1.01 ; p<0.0001$; Mann-Whitney test), whereas PA contained the smallest number $\left(\mathrm{m}_{\text {peri }}=6.09\right.$; $\mathrm{m}_{\text {intra }}=1.57 ; p<0.0003$; Mann-Whitney test). Intraparenchymal mast cell staining varied significantly between the different groups of tumors $(p<0.0001$; Kruskal-Wallis test). The ACC exhibited the smallest number of intraparenchymal mast cell $\left(\mathrm{m}_{\text {intra }}=0.13 ; \mathrm{m}_{\text {peri }}=7.45\right.$; $p<0.0007$; Mann-Whitney test). The higher number of intraparenchymal mast cell staining was observed in PA and MEC, with the observation of a significant difference when comparing MEC versus ACC $(p<0.001$; KruskalWallis test and Dunn's post-test) and PA versus MEC ( $p<$ 0.001; Kruskal-Wallis test and Dunn's post-test). Table 1 summarizes the results of statistical analysis.

The different histological patterns of ACC (cribriform: $p<$ 0.0079 and tubular: $p<0.0556$; Mann-Whitney test) showed a significantly larger number of mast cells in periparenchymal areas in relation to intraparenchymal areas.

Microvessel staining using anti-factor VIII antibody was seen in almost all tumors (Fig. 2), except for one case of PA and two cases of PLGA. Elongated or round, sometimes collapsed, vessels without a lumen were seen. The vessels were found mainly near the tumor parenchyma, irrespective of histological subtype. In normal salivary glands, few vessels were detected in the glandular stroma. The highest microvessel density was observed in MEC, followed by ACC, PA, and PLGA (Fig. 3). This difference was statistically significant when MEC was compared to PA ( $p=0.0034$, Mann-Whitney test) and PLGA ( $p=0.004$, Mann-Whitney test). Microvessel density was significantly higher in ACC when compared to PA ( $p=0.0406$, Mann-Whitney test) and PLGA ( $p=0.0123$, Mann-Whitney test). However, no significant difference in microvessel density was observed between ACC and MEC ( $p=0.3627$, Mann-Whitney test), between PA and PLGA ( $p=$ 0.5935, Mann-Whitney test), or between the histological subtypes of ACC ( $p=0.1732$, Mann-Whitney test). Comparison of mast cell density versus vessel density showed no significant difference for any of the tumors studied (MEC: $p=0.832$; ACC: $p=0.0593$; PLGA: $p=0.3976$; PA: $p=0.6714$; MannWhitney test).

\section{Discussion}

Our results showed that the mast cell and microvessel densities were higher in MEC when compared to PA. Taken together, the results obtained for these two neoplasms and for ACC and PGLA permit to speculate about the influence of myoepithelial cells on the aggressiveness of malignant salivary gland tumors $[9,25,30-34]$.

To our knowledge, little is known about the distribution of MCs in minor salivary gland tumors [35-37], although some studies have described these cells in tumors originated from major salivary glands [36-43]. However, most of these studies have focused on Warthin tumors, using different methodologies [38-44]. In addition, previous studies have demonstrated a higher number of MCs in the peritumoral area [36, 41, 45]. In the study of Katopodi et al. [36], the authors detected no intraparenchymal MCs in PAs. This finding is in contrast to the present study in which intraparenchymal MCs were observed in this benign tumor, as well as in MEC, ACC, and PLGA.

MCs were more frequently found in the periparenchymal areas than in the intraparenchymal areas. Despite this distribution, some investigators observed a similar peritumoral distribution of MCs in malignant tumors of different origins $[46,47]$. This mast cell distribution has also been seen by our team in odontogenic tumors [28]. According to Maltby, Khazaie and McNagny [10], the peritumoral location of mast cells suggests that the recruitment of these cells occurs in two ways: migration of MCs from neighboring healthy tissues, or migration of mast cell progenitors through blood vessels near the tumor. The extracellular matrix might also influence this finding, as MCs have a high affinity for the 

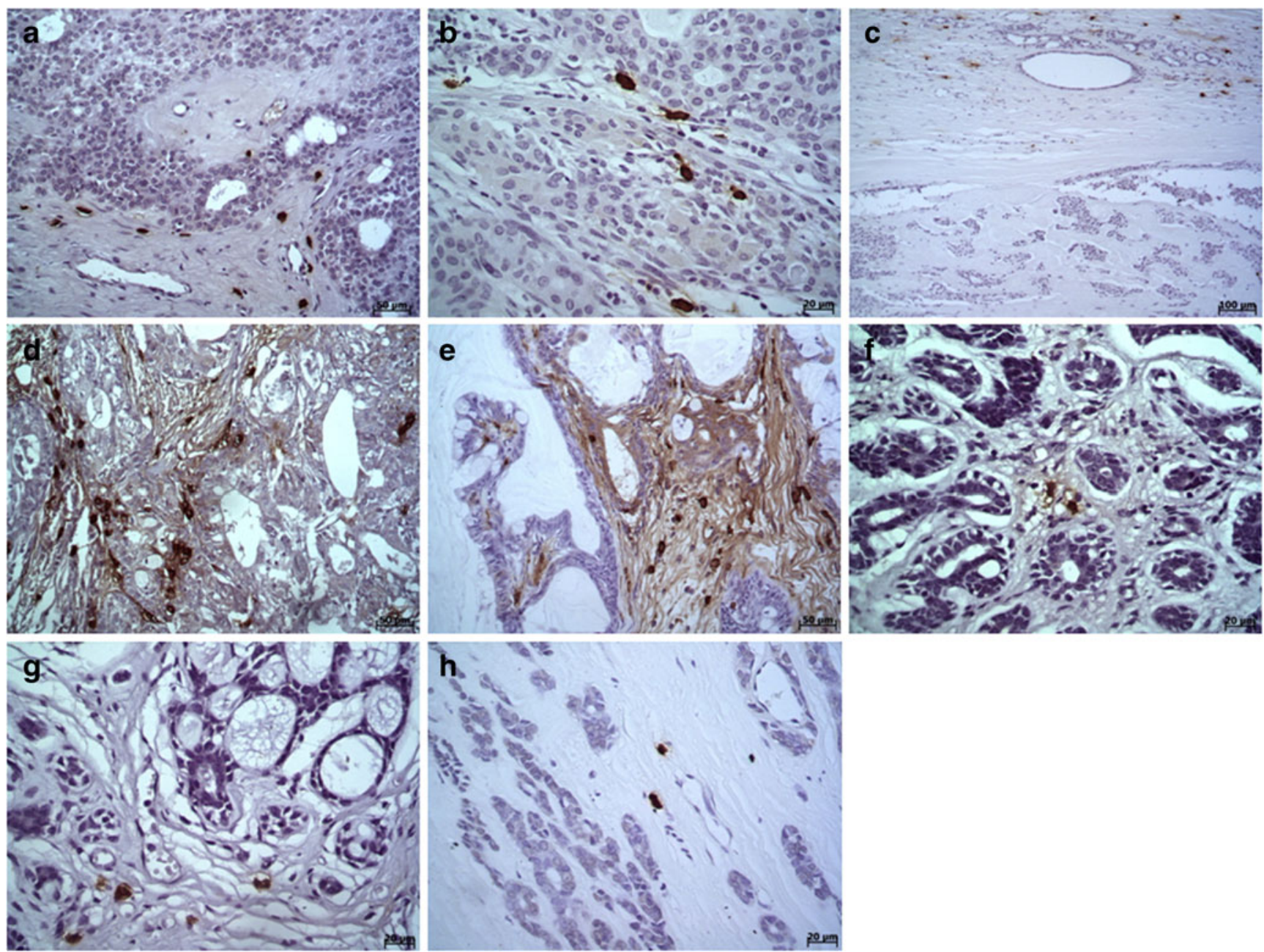

Fig. 1 Pleomorphic adenoma: elongated and oval mast cells located in the extracellular matrix close to tumor parenchyma (a). Oval mast cells located in the tumor parenchyma amidst ovoid to plasmacytoid cells (b). Note mast cells concentrated on fibrous capsule (c). Mucoepidermoid carcinoma: accumulation of mast cells mainly in the tumor stroma (d).

Papillary cystic growth showing mast cells with variable shape (e). Cystic adenoid carcinoma: tubular pattern showing a few mast cells in the periparenchymal region (f). Cribriform pattern showing mast cells close to blood vessels (g). Polymorphous low-grade adenocarcinoma: note a few mast cells close to blood vessels and distributed in hyaline stroma (h)

adsorption to fibronectin induced by stem cell factor (SFC) or from integrin receptors [48-50].

In the present study, a significant difference in mast cell count was observed between the periparenchymal and intraparenchymal regions. However, this variation in the intraparenchymal region called attention since the sequential mean differed from that of the periparenchymal region. The meaning of this result in the intraparenchymal region

seems to be conflicting as demonstrated by different investigators. Studies on prostate cancer have demonstrated a relationship between mast cell distribution and tumor prognosis, with intratumoral MCs being related to a better prognosis, whereas peritumoral MCs are associated with a poor prognosis [51, 52]. In contrast, Watanabe et al. [53] showed an inverse proportion between cell apoptosis and intratumoral mast cell tryptase density in patients with hemodialysis-renal

Table 1 Density of mast cells and their distributions (Mann-Whitney test)

\begin{tabular}{|c|c|c|c|c|}
\hline Tumor type & Total density (cells $/ \mathrm{mm}^{2}$ ) & Periparenchymal density & Intraparenchymal density & $p$ value \\
\hline Pleomorphic adenoma & 7.66 & 6.09 & 1.57 & $<0.0003$ \\
\hline Mucoepidermoid carcinoma & 11.5 & 10.49 & 1.01 & $<0.0001$ \\
\hline Cystic adenoid carcinoma & 7.58 & 7.45 & 0.13 & $<0.0007$ \\
\hline Low-grade polymorphic adenocarcinoma & 7.04 & 6.66 & 0.38 & $<0.0001$ \\
\hline
\end{tabular}


Fig. 2 Immunostaining of blood vessels located in the stroma corresponding to pleomorphic adenoma (a), mucoepidermoid carcinoma (b), adenoid cystic carcinoma (c) polymorphous low-grade adenocarcinoma (d)
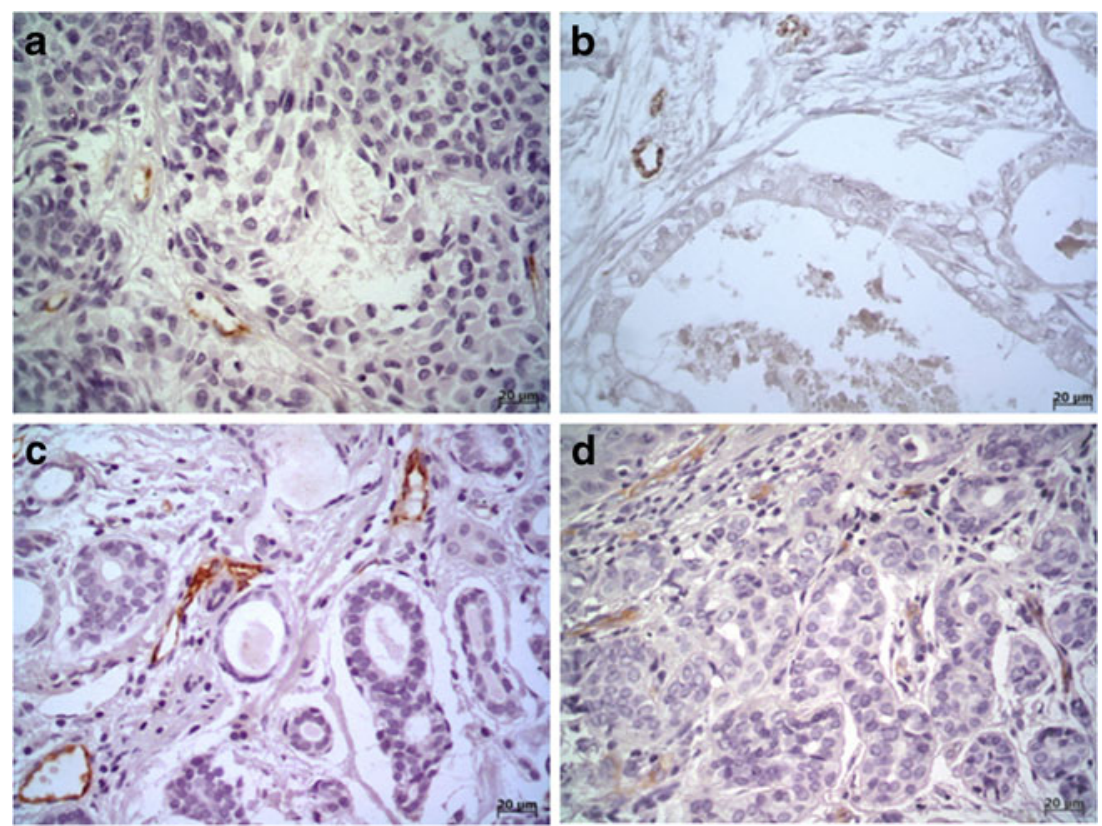

cell carcinoma, as well as a higher proliferation index, local invasion, and metastasis in some of these cases. In the present study, the highest intraparenchymal mast cell density was observed in MECs when compared to the other malignant tumors, as well as when compared to periparenchymal MCs. Studies involving a larger number of cases and tumors with variable grades of malignancy may help clarify this aspect.

An interesting finding was the high concentration of $\mathrm{MCs}$ in areas of fibrosis seen in many PA cases, as well as in the fibrous matrix of the other malignant tumors studied. Ahmed et al. [54] suggested a direct relationship between mast cells and intramedullary fibrosis. Pereira et al. [28] raised the hypothesis of the growth and expansion of

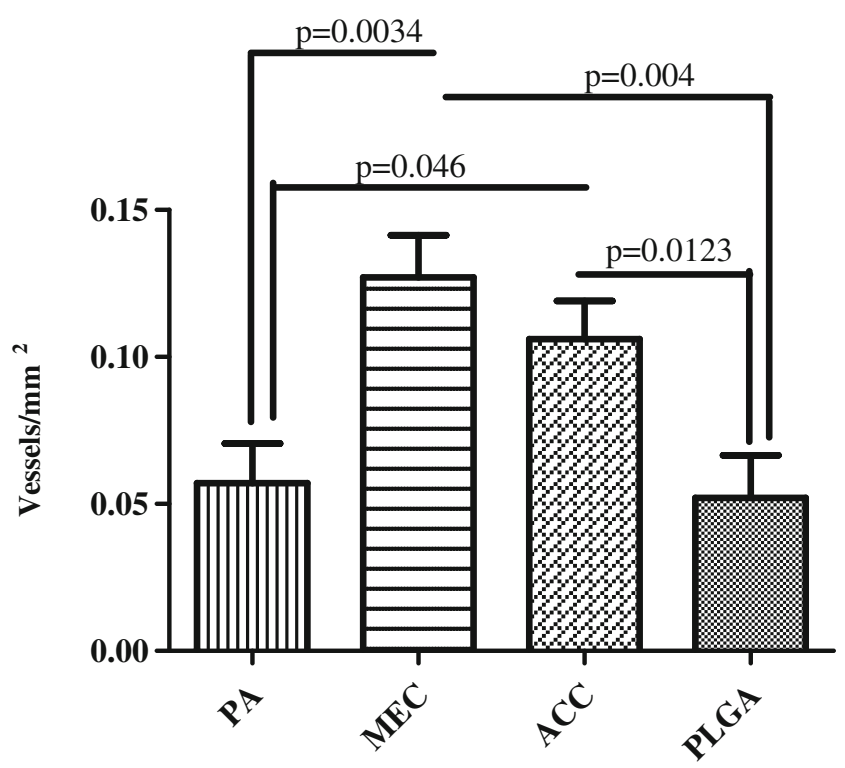

Fig. 3 Microvessel density in minor salivary gland tumors odontogenic tumors through collagen synthesis mediated by MCs. The tissue remodeling capacity of MCs through the synthesis of collagen has been suggested to be due to the release of fibrogenic molecules such as TGF-beta [55]. Mangia et al. [17] showed that during breast cancer progression, MCs contribute to tissue remodeling characterized by the differentiation of fibroblasts into myofibroblasts through the release of mast cell tryptase into the tumor stroma. Therefore, the rich extracellular matrix produced through these mechanisms may explain the higher mast cell density found in PAs when compared ACCs and PLGAs. In addition the capsular fibrosis mediated by MCs and commonly seen in PAs may influence tumor growth.

The histology of salivary gland tumors is complex, and several studies have tried to identify biomarkers that help distinguish these tumors [8, 56-58]. In this respect, although the mast cell population does not contribute to the morphological distinction of these tumors, it can be used to identify differences in the biological behavior between PAs and mucoepidermoid and cystic adenoid carcinomas since mean periparenchymal mast cell numbers were higher in the last two tumors. In addition, we observed little difference in mast cell density between PAs and PLGAs. This finding might be related to the low aggressiveness of the latter which shows low rates of metastasis and recurrence [59].

The observation of MCs around blood vessels suggests an intimate communication between this cell population and the tumor vasculature [58]. This feature makes a favorable environment for neoplastic development which involves signaling molecules that regulate mast cell biology during tumorigenesis. MCs play an important role in the process of extracellular matrix remodeling during neoplastic transformation, secreting proteolytic enzymes that favor the migration of endothelial and 
tumors cells, and angiogenic factors stored in stromal tissue [10, 60-62].

Microvessel density was significantly higher in MEC and ACC when compared to PA and PLGA, a finding supporting the aggressive behavior of these malignant tumors. Although they used other vascular markers, Cardoso et al. [25] also demonstrated a higher microvessel density in MEC, followed by PGLA. Similar findings have been reported by Demasi et al. [63]. This high density of microvessels in MECs might be attributed to the absence of myoepithelial content in these tumors [25, 33, 34]. Further, myoepithelial cells secrete proteinases and express genes that inhibit angiogenesis, promoting a tumor environment that does not favor the formation of blood vessels and consequent tumor development $[9,31-33]$. It is therefore believed that human myoepithelial cells, even when transformed, are natural suppressors of angiogenesis [9].

We found no significant difference in mast cell distribution or microvessel density between the different tumors studied. This lack of significant difference has also been reported by some investigators for different malignant tumors [47, 64-66], but not by others [67, 68]. However, we demonstrated that microvessel density was similar in PA and PLGA, but still lower than in MEC and ACC. this finding might be explained by the fact that the first two tumors are well differentiated. In addition, we found no difference in mast cell count or microvessel density between the cribriform and tubular subtypes of ACC. However, an increased mast cell population was observed in the solid variant, but this variant was only represented by one case. Further studies are needed to analyze the density of mast cells in the solid variant, which shows a poor prognosis that might be related to a larger number of MCs. It is important to state that the lack of myoepithelial differentiation results in a higher proportion of proangiogenic factors compared to antiangiogenic factors, thus favoring tumor development.

Finally, although the present study failed to demonstrate a significant relationship between mast cell and microvessel density in different salivary gland tumors, a quantitative difference in MCs and microvessels was observed, particularly in MEC, a finding supporting the aggressive behavior of malignant salivary gland tumors without myoepithelial differentiation. Further studies are needed to determine the role of mast cells in angiogenesis, as well as in the development and biological behavior of these tumors.

Acknowledgments This study was supported by Conselho Nacional de Desenvolvimento Científico e Tecnológico (CNPq).

Conflict of interest None.

\section{References}

1. Toida M, Shimokawa K, Makita H, Toida M, Shimokawa K, Makita $\mathrm{H}$, et al. Intraoral minor salivary gland tumors: a clinicopathological study of 82 cases. Int J Oral Maxillofac Surg. 2005;34:528-32.

2. Vicente OP, Marqués NA, Aytés LB, Escoda CG. Minor salivary gland tumors: a clinicopathological study of 18 cases. Med Oral Patol Oral Cir Bucal. 2008;13:582-8.

3. Barros AC, Gurgel CAS, Gomes MC, Agra IMG, Kruschewsky LS, Santos JN. Minor salivary gland tumors in a South American population. Arch Oncol. 2010;18:56-9.

4. Yih WY, Kratochvil FJ, Stewart JCB. Intraoral minor salivary gland neoplasms: review of 213 cases. J Oral Maxillofac Surg. 2005;63:805-10.

5. Li LJ, Li Y, Wen YM, Liu H, Zhao HW. Clinical analysis of salivary gland tumor cases in West China in past 50 years. Oral Oncol. 2008;44:187-92.

6. Ben-Izhak O, Akrish S, Nagler RM. Ki-67 and salivary cancer. Cancer Invest. 2008;26:1015-23.

7. Demasi AP, Costa AF, Altemani A, Furuse C, Araújo NS, Araújo VC. Glucose transporter protein 1 expression in mucoepidermoid carcinoma of salivary gland: correlation with grade of malignancy. Int J Exp Pathol. 2010;91:107-13.

8. Dultra FK, Barros AC, Schaer-Barbosa H, Figueiredo AL, Gurgel CA, Ramos EA, et al. Immunohistochemical assessment of CD1apositive Langerhans cells and their relationship with E-cadherin in minor salivary gland tumors. J Oral Pathol Med. 2012;41:47-53.

9. Nguyen M, Lee MC, Wang JL, Tomlinson JS, Shao ZM, Alpaugh ML, et al. The human myoepithelial cell displays a multifaceted anti-angiogenic phenotype. Oncogene. 2000;19:3449-59.

10. Maltby S, Khazaie K, Mcnagny KM. Mast cells in tumor growth: angiogenesis, tissue remodelling and immune-modulation. Biochim Biophys Acta. 2009;1796:19-26.

11. Xiang M, Gu Y, Zhao F, Lu H, Chen S, Yin L. Mast cell tryptase promotes breast cancer migration and invasion. Oncol Rep. 2010;23:615-9.

12. Ribatti D, Crivellato E, Roccaro AM, Ria R, Vacca A. Mast cell contribution to angiogenesis related to tumour progression. Clin Exp Allergy. 2004;34:1660-4.

13. Rodewald HR, Dessing M, Dvorak AM, Galli SJ. Identification of a committed precursor for the mast cell lineage. Science. 1996;271:818-22.

14. Chen CC, Grimbaldeston MA, Tsai M, Weissman IL, Galli SJ. Identification of mast cell progenitors in adult mice. Proc Natl Acad Sci USA. 2005;102:11408-13.

15. Fukushima H, Ohsawa M, Ikura Y, et al. Mast cells in diffuse large Bcell lymphoma; their role in fibrosis. Histopathology. 2006;49:498-505.

16. Theoharides TC, Conti P. Mast cells: the Jekyll and Hyde of tumor growth. Trends Immunol. 2004;25:235-41.

17. Mangia A, Malfettone A, Rossi R, Paradiso A, Ranieri G, Simone $\mathrm{G}$, et al. Tissue remodelling in breast cancer: human mast cell tryptase as an initiator of myofibroblast differentiation. Histopathology. 2011;58:1096-106.

18. Norrby K. Mast cells and angiogenesis. APMIS. 2002;110:355-71.

19. Conti P, Castellani ML, Kempuraj D, Salini V, Vecchiet J, Tetè S, et al. Role of mast cells in tumor growth. Ann Clin Lab Sci. 2007;37:315-22.

20. Ribatti D, Crivellato E, Molica S. Mast cells and angiogenesis in haematological malignancies. Leuk Res. 2009;33:876-9.

21. Ribatti D, Crivellato E, Candussio L, Nico B, Vacca A, Roncali L, et al. Mast cells and their secretory granules are angiogenic in the chick embryo chorioallantoic membrane. Clin Exp Allergy. 2001;31:602-8.

22. Wasiuk A, Vries VC, Hartmann K, Roers A, Noelle RJ. Mast cells as regulators of adaptive immunity to tumours. Clin Exp Immunol. 2009;155:140-6. 
23. Zhang S, Li L, Lin J, Lin H. Imbalance between expression of matrix metalloproteinase- 9 and tissue inhibitor of metalloproteinase- 1 in invasiveness and metastasis of human gastric carcinoma. World $\mathrm{J}$ Gastroenterol. 2003;9:899-904.

24. Crivellato E, Nico B, Ribatti D. Mast cells and tumour angiogenesis: new insight from experimental carcinogenesis. Cancer Lett. 2008;269:1-6

25. Cardoso S, Souza K, Faria P, Eisenberg A, Dias F, Loyola A. Assessment of angiogenesis by cd105 antigen in epithelial salivary gland neoplasms with diverse metastatic behavior. BMC Cancer. 2009;9:391.

26. De Wever O, Mareel M. Role of tissue stroma in cancer cell invasion. J Pathol. 2003;200:429-47.

27. Barnes L, Jw E, Reichart P, Sidransky D. World health organization classification of tumours. Lyon: Pathology and genetics of head and neck tumours IARC; 2005.

28. De Assis Caldas Pereira F, Gurgel CA, Ramos EA, Vidal M, Pinheiro AL, Jurisic V, et al. Distribution of mast cells in benign odontogenic tumors. Tumour Biol. 2012;33:455-61.

29. Guttman D, Stern Y, Shpitzer T, Ulanovski D, Druzd T, Feinmesser R. Expression of MMP-9, TIMP-1, CD-34 and factor-8 as prognostic markers for squamous cell carcinoma of the tongue. Oral Oncol. 2004;40:798-803.

30. Sternlicht MD, Barsky SH. The myoepithelial defense: a host defense against cancer. Med Hypotheses. 1997;48:37-46.

31. Barsky S, Karlin N. Myoepithelial cells: autocrine and paracrine suppressors of breast cancer progression. J Mammary Gland Biol Neoplasia. 2005;10:249-60.

32. Polyak K, Hu M. Do myoepithelial cells hold the key for breast tumor progression? J Mammary Gland Biol Neoplasia. 2005;10:231-47.

33. Soares AB, Juliano PB, Araujo VC, Metze K, Altemani A. Angiogenic switch during tumor progression of carcinoma expleomorphic adenoma. Virchows Arch. 2007;451:65-71.

34. Costa AF, Demasi AP, Bonfitto VL, Bonfitto JF, Furuse C, Araújo $\mathrm{VC}$, et al. Angiogenesis in salivary carcinomas with and without myoepithelial differentiation. Virchows Arch. 2008;453:359-67.

35. Holst VA, Marshall CE, Moskaluk CA, Frierson Jr HF. Kit protein expression and analysis of c-kit gene maturation mutation in adenoid cystic carcinoma. Mod Pathol. 1999;12:956-60.

36. Katopodi E, Kavantzas N, Pavlopoulos P, Papanikolaou V, Saetta A, Korkolopoulou P, et al. The frequency and distribution of mast cells in pleomorphic adenomas of salivary glands. Pathology. 2004;36:258-61.

37. Gonzalez-Arriagada WA, Santos-Silva AR, Ito FA, Vargas PA, Speight PM, Bingle L, et al. Expression pattern of plunc proteins as an auxilary tool for the diagnosis of high-grade mucoepidermoid carcinoma of the salivary gland. J Oral Pathol Med. 2012;41:589-97.

38. Korsud FR, Brandtzacz P. Immunochemical characterization of cellular immunogolobulin and epithelial marker antigen in warthin tumor. Human Pathol. 1984;15:361-67.

39. Caselitz J, Salfelder A, Seifert G. Klin Wochemschr. 1984;62:284-6.

40. Bottles K, Lowhagen T, Miller TR. Mast cells in the aspiration cytology differential diagnosis of adenolymphoma. Acta Cytol. 1985;29:513-15.

41. Yamamoto H, Caselitz J, Seifert G. Cystadenolymphoma: an immunohistochemical study with special reference to Ig E and mast cells. Pathol Res Pract. 1985;180:364-8.

42. Kobayashi TK, Ueda M, Nishio T, Kushina R, Nakajima S, Kaneco C. Association of mast cells with Warthin's tumor in fine needle aspirates of the salivary gland. Acta Cytol. 1999;43:1052-58.

43. Flezar M, Pogacnik A. Warthin's tumour: unusual vs common morphological findings in the fine needle aspiration biopsies. Cytopathology. 2002;13:232-41.

44. Matsuzaka K, Kokubu E, Takeda E, Tanaka Y, Shimono M, Inoue T. Papillary cystadenoma arising from the upper lip: a case report. Bull Tokyo Dent Coll. 2003;44:213-16.
45. Nemolato S, Cabras T, Fanari MU, et al. Thymosin beta 4 expression in normal skin, colon mucosa and in tumor infiltrating mast cells. Eur J Histochem. 2010;54:14-7.

46. Tóth-Jakatics R, Jimi S, Takebayashi S, Kawamoto N. Cutaneous malignant melanoma: correlation between neovascularization and peritumor accumulation of mast cells overexpressing vascular endothelial growth factor. Hum Pathol. 2000;31:955-60.

47. Carlini MJ, Dalurzo MC, Lastiri JM. Smith De, Vasallo BC, Puricelli LI, Lauría De Cidre LS. Mast cell phenotypes and microvessels in non-small cell lung cancer and its prognostic significance. Hum Pathol. 2010;41:697-705.

48. Wayner A, Carter G, Piotrowicz S, Kunick TJ. The function of multiple extracellular matrix receptors in mediating cell adhesion to extracellular matrix: preparation of monoclonal antibodies to the fibronectin receptor that specifically inhibit cell adhesion to fibronectin and react with platelet glycoproteins ic-iia. J Cell Biol. 1988;107:1881-91.

49. Dastuch J, Costa J, Thompson H, Metcalf TD. Mast cell adhesion to fibronectin. Immunology. 1991;73:478-84.

50. Dastych J, Metcalfe DD. Stem cell factor induces mast cell adhesion to fibronectin. J Immunol. 1994;152:213-9.

51. Fleischmann A, Schlomm T, Köllermann J, Sekulic N, Huland H, Mirlacher M, et al. Immunological microenvironment in prostate cancer: high mast cell densities are associated with favorable tumor characteristics and good prognosis. Prostate. 2009;69:976-81.

52. Johansson A, Rudolfsson S, Hammarsten P, Halin S, Pietras K, Jones J, et al. Mast cells are novel independent prognostic markers in prostate cancer and represent a target for therapy. Am J Pathol. 2010;177:1031-41.

53. Watanabe S, Miyata Y, Matsuo T, Mochizuki Y, Nishikido M, Hayashi T, Sakai H. (2011). High density of tryptase-positive mast cells in patients with renal cell carcinoma on hemodialysis: correlation with expression of stem cell factor and protease activated receptor-2 hum pathol. doi:10.1016/j.humpath.2011

54. Ahmed A, Powers MP, Youker KA, Rice L, Ewton A, Dunphy $\mathrm{CH}$, et al. Mast cell burden and reticulin fibrosis in the myeloproliferative neoplasms: a computer-assisted image analysis study. Pathol Res Pract. 2009;205:634-8.

55. Tefferi A. Pathogenesis of myelofibrosis with myeloid metaplasia. J Clin Oncol. 2005;23:8520-30.

56. Vargas PA, Cheng Y, Barret AW, Craig GT, Speight PM. Expression of MCM-2, KI-67 and geminin in benign and malignant salivary gland tumours. J Oral Pathol Med. 2003;37:309-18.

57. Araújo VC, Furuse C, Cury PR, Altemani A, Alves VA, De Araújo NS. Tenascin and fibronectin expression in carcinoma ex pleomorphic adenoma. Appl Immunohistochem Mol Morphol. 2008;16:48-53.

58. Araújo CP, Gurgel CA, Ramos EA, Freitas VS, Barbosa Ade Jr A, Ramalho LM, et al. Accumulation of CD1a-positive Langerhans cells and mast cells in actinic cheilitis. J Mol Histol. 2010;2010 (41):357-65.

59. Paleri V, Robinson M, Bradley P. Polymorphous low-grade adenocarcinoma of the head and neck. Curr Opin Otolaryngol Head Neck Surg. 2008;16:163-9.

60. Stack MS, Johnson DA. Human mast cell tryptase activates singlechain urinary-type plasminogen activator (pro-urokinase). J Biol Chem. 1994;269:9416-9.

61. Reed JA, Mcnutt NS, Bogdany JK, Albino AP. Expression of the mast cell growth factor interleukin-3 in melanocytic lesions correlates with an increased number of mast cells in the perilesional stroma: implications for melanoma progression. J Cutan Pathol. 1996;23:495-505.

62. Vacca A, Ria R, Ribatti D, Semeraro F, Djonov V, Di Raimondo F, et al. A paracrine loop in the vascular endothelial growth factor pathway triggers tumor angiogenesis and growth in multiple myeloma. Haematologica. 2003;88:176-85. 
63. Demasi AP, Silva CA, Silva AD, Furuse C, Soares AB, Altemani A, et al. Expression of the vascular endothelial growth factor and angiopoietins in mucoepidermoid carcinoma of salivary gland. Head Neck Pathol. 2012;6:10-5.

64. Tuna B, Yorukoglu K, Unlu M, Mungan M, Kirkali Z. Association of mast cells with microvessel density in renal cell carcinomas. Eur Urol. 2006;50:530-4.

65. Gulubova M, Vlaykova T. Prognostic significance of mast cell number and microvascular density for the survival of patients with primary colorectal cancer. J Gastroenterol Hepatol. 2009;24:1265-75.
66. Chan JK, Magistris A, Loizzi V, Lin F, Rutgers J, Osann K, et al. Mast cell density, angiogenesis, blood clotting, and prognosis in women with advanced ovarian cancer. Gynecol Oncol. 2005;99:20-5.

67. Mohseni MG, Mohammadi A, Heshmat A, Kosari F, Meysamie AP. The lack of correlation between mast cells and microvessel density with pathologic feature of renal cell carcinoma. Int Urol Nephrol. 2010;42:109-12.

68. Ribatti D, Finato N, Crivellato E, Marzullo A, Mangieri D, Nico B, et al. Neovascularization and mast cells with tryptase activity increase simultaneously with pathologic progression in human endometrial cancer. Am J Obstet Gynecol. 2005;193:1961-5. 